\title{
Correction to: Dynamic modeling and control of five phase SVPWM inverter fed induction motor drive with intelligent speed controller
}

\author{
D. Raja ${ }^{1}$ (D.G. Ravi ${ }^{1}$
}

๑) Springer-Verlag GmbH Germany, part of Springer Nature 2020

\section{Correction to: Journal of Ambient Intelligence and Humanized Computing}

https://doi.org/10.1007/s12652-020-01717-5

In the original publication of the article, the acknowledgment section was missed. The acknowledgment should read as follows:

Acknowledgements The corresponding author would like to thank Sri Manakula Vinayagar Engineering College, Puducherry, India for their constant support for this research work.

Publisher's Note Springer Nature remains neutral with regard to jurisdictional claims in published maps and institutional affiliations.

The original article can be found online at https://doi.org/10.1007/ s12652-020-01717-5.

D. Raja

rajaapeee@smvec.ac.in

G. Ravi

ravig@pec.edu

1 Department of Electrical and Electronics Engineering,

Pondicherry Engineering College, Pillaichavady,

Puducherry 605014, India 